\title{
Sensory Neuron-Specific Deletion of TRPA1 Results in Mechanical Cutaneous Sensory Deficits
}

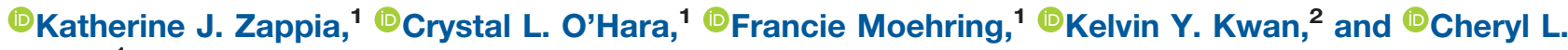 \\ Stucky ${ }^{1}$
}

DOI:http://dx.doi.org/10.1523/ENEURO.0069-16.2017

${ }^{1}$ Department of Cell Biology, Neurobiology and Anatomy, Medical College of Wisconsin, Milwaukee, WI 53226, and

${ }^{2}$ Department of Cell Biology and Neuroscience, Rutgers, The State University of New Jersey, Piscataway, NJ 08854

\begin{abstract}
The nonselective cation channel transient receptor potential ankyrin 1 (TRPA1) is known to be a key contributor to both somatosensation and pain. Recent studies have implicated TRPA1 in additional physiologic functions and have also suggested that TRPA1 is expressed in nonneuronal tissues. Thus, it has become necessary to resolve the importance of TRPA1 expressed in primary sensory neurons, particularly since previous research has largely used global knock-out animals and chemical TRPA1 antagonists. We therefore sought to isolate the physiological relevance of TRPA1 specifically within sensory neurons. To accomplish this, we used Advillin-Cre mice, in which the promoter for Advillin is used to drive expression of Cre recombinase specifically within sensory neurons. These Advillin-Cre mice were crossed with Trpa $1^{\mathrm{fl} / \mathrm{fl}}$ mice to generate sensory neuron-specific Trpa1 knock-out mice. Here, we show that tissue-specific deletion of TRPA1 from sensory neurons produced strong deficits in behavioral sensitivity to mechanical stimulation, while sensitivity to cold and heat stimuli remained intact. The mechanical sensory deficit was incomplete compared to the mechanosensory impairment of TRPA1 global knock-out mice, in line with the incomplete ( $80 \%)$ elimination of TRPA1 from sensory neurons in the tissue-specific Advillin-Cre knock-out mice. Equivalent findings were observed in tissue-specific knock-out animals originating from two independently-generated Advillin-Cre lines. As such, our results show that sensory neuron TRPA1 is required for mechanical, but not cold, responsiveness in noninjured skin.
\end{abstract}

Key words: advillin; cold; mechanical; sensory neuron; somatosensation; TRPA1

\section{Significance Statement}

To date, most studies on the function of transient receptor potential ankyrin 1 (TRPA1) have used either global knock-out animals or antagonists, which do not allow for tissue specificity in their interpretation. Given that TRPA1 is expressed in multiple cell types, cell-type-specific targeting is necessary to elucidate the mechanisms through which TRPA1 facilitates mechanosensation and other physiologic functions. Our results show that deletion of TRPA1 from sensory neurons is sufficient to induce significant impairment in baseline mechanical sensitivity but does not impact behavioral cold aversion. Beyond the important clarification that the expression of TRPA1 specifically within sensory neurons is necessary for mechanosensation in mouse, sensory neuron-specific TRPA1 knock-out animals will be beneficial in future studies focused on isolating additional tissue-specific functions of TRPA1.

Received March 22, 2016; accepted January 30, 2017; First published February 10, 2017.

The authors declare no competing financial interests.
Author contributions: K.J.Z. and C.L.S. designed research; K.J.Z., C.L.O., F.M., K.Y.K. performed research; K.J.Z. and C.L.S. analyzed data; K.J.Z. and C.L.S. wrote the paper. 


\section{Introduction}

The ion channel transient receptor potential ankyrin 1 (TRPA1) is a polymodal, nonselective cation channel that is activated by chemical, thermal, and mechanical stimuli (Bandell et al., 2004; Vilceanu and Stucky, 2010; Brierley et al., 2011; Wang et al., 2011; Zayats et al., 2013). Key ion channels expressed within mechanically-activated sensory neurons include Piezo2 and TRPA1 (Story et al., 2003; Julius, 2013; Ranade et al., 2014). Much work has been done to elucidate the methods through which various mechanosensitive channels, including Piezo1 and Piezo2 in mammals and MscL in bacteria, sense mechanical force. Evidence suggests some ion channels are intrinsically sensitive to deformation of a plasma membrane or simplified lipid bilayer (Blount et al., 1996; Coste et al., 2010; Kung et al., 2010; Ranade et al., 2014; Cox et al., 2016). Secondly, several ion channels can be activated following indirect mechanical stress to the cell membrane and associated cytoskeleton (Nilius and Honoré, 2012; Brohawn et al., 2014). As such, TRPA1 may indirectly sense forces transmitted through the cytoskeleton to TRPA1's many intracellular ankyrin repeats (Corey et al., 2004; Paulsen et al., 2015).

Soon after its initial identification in sensory neurons, TRPA1 became a central focus in the study of pain and mechanical hyperalgesia (Story et al., 2003; Bautista et al., 2006) and was recognized as integral to mechanical sensitization in a number of pain states, including acute and chronic inflammation, nerve injury, and diabetic neuropathy (Eid et al., 2008; Lennertz et al., 2012; Bautista et al., 2013; Garrison and Stucky, 2014). TRPA1 is similarly important for baseline mechanosensation (Kwan et al., 2006; Vilceanu and Stucky, 2010).

Beyond its role in mechanosensation, TRPA1 has been subject to debate regarding its role in cold sensation. Cumulative evidence shows that TRPA1 contributes to cold hypersensitivity during injury (Obata et al., 2005; del Camino et al., 2010; Zhao et al., 2012); however, its contribution to baseline thermal sensation is less clear, possibly due to functional similarly to other cold-sensing ion channels, like TRPM8 (Bautista et al., 2007; Colburn et al., 2007), which may allow for retained baseline be-

This research was supported by NIH Grants NS040538 and NS070711 (to C.L.S.) and NS087716 (to K.J.Z.). Funding for K.Y.K. was through the Duncan and Nancy MacMillan Faculty Development Chair Endowment Fund, Busch Biomedical Research Grant, Rutgers Faculty Development Grant, and the $\mathrm{NIH}$ Grant R01 DC015000-01. Partial support was provided by the Research and Education Component of the Advancing a Healthier Wisconsin Endowment at the Medical College of Wisconsin. K.J.Z. is a member of the MCW-MSTP, which is partially supported by a T32 grant from NIGMS, GM080202.

Acknowledgements: We thank Andy Weyer for his thoughtful review of the manuscript. Trpa $1^{\mathrm{fl} / \mathrm{fl}}$ animals were originally generated by Kelvin Y. Kwan in David P. Corey's lab.

Correspondence should be addressed to either of the following: Cheryl L. Stucky, 8701 Watertown Plank Road, Milwaukee, WI 53226, E-mail: cstucky@mcw.edu; or Katherine J. Zappia, 8701 Watertown Plank Road, Milwaukee, WI 53226, E-mail: kzappia@mcw.edu.

DOI:http://dx.doi.org/10.1523/ENEURO.0069-16.2017

Copyright @ 2017 Zappia et al.

This is an open-access article distributed under the terms of the Creative Commons Attribution 4.0 International, which permits unrestricted use, distribution and reproduction in any medium provided that the original work is properly attributed. havioral sensitivity to cold in the absence of TRPA1. In heterologous expression systems or sensory neurons, murine TRPA1 is activated by noxious cold stimulation (Story et al., 2003; Karashima et al., 2009). However, it appears that TRPA1 is not necessary for baseline cold sensation behaviorally (Kwan et al., 2009; Knowlton et al., 2010). Naïve global TRPA1 knock-out mice were shown to have normal behavioral responses to cold, from $-10^{\circ} \mathrm{C}$ to $20^{\circ} \mathrm{C}$, and to radiant heat (Bautista et al., 2006). Interestingly, TRPA1 may still function in an uninjured state as a cold sensor; for example, TRPA1 is important in mediating the vascular response to environmental cold stimuli (Aubdool et al., 2014).

Although significant evidence has shown that TRPA1 contributes to hyperalgesia, these findings have not resolved whether the TRPA1's contribution to somatosensation is tissue specific. It has been widely assumed that the effects of TRPA1 are mediated primarily by its presence in sensory neurons (Story et al., 2003; Corey et al., 2004; Julius, 2013); however, there are reports identifying TRPA1 expression in other cell types, including astrocytes and keratinocytes (Atoyan et al., 2009; Kwan et al., 2009; Shigetomi et al., 2012). Indeed, most studies of TRPA1 have used global knock-out mice (Kwan et al., 2006; Brierley et al., 2009; Kwan and Corey, 2009) or pharmacologic antagonists (Petrus et al., 2007; Eid et al., 2008; Kerstein et al., 2009), which lack cell-type specificity.

Given the possibility of TRPA1 expression in other cell types, we sought to isolate the contribution of TRPA1 expressed by primary sensory neurons to cutaneous sensation. To do so, we used Advillin-Cre mice (da Silva et al., 2011; Zurborg et al., 2011) to express Cre recombinase in sensory neurons. Advillin, an actin-binding protein involved in development of peripheral ganglion neurons, is a highly selective marker of peripheral sensory neurons within the dorsal and trigeminal ganglia (Hasegawa et al., 2007). Further, this occurs without apparent preference for particular subpopulations of sensory neurons (Zurborg et al., 2011). As such, this Advillin-Cre transgene is an effective method of driving Cre-mediated recombination in a majority ( $\geq 80 \%$ ) of sensory neurons of all subclasses (Pagadala et al., 2013; Ranade et al., 2014). Crossing Advillin-Cre mice with a mouse containing loxP sites flanking the exons encoding the pore region of Trpa1 $\left(\right.$ Trpa $^{\mathrm{fl} / \mathrm{fl}}$ mice) allowed generation of sensory neuronspecific TRPA1 knock-out mice. Our findings show that sensory neuron-specific knock-out of TRPA1 significantly impairs mechanosensation, while leaving thermal sensation intact.

\section{Materials and Methods}

\section{Animal generation and use}

In order to address the role of Trpa1 specifically within sensory neurons, we sought to create a conditional knock-out animal. Mice containing loxP sites flanking exons 22 through 24 of the Trpa1 gene were used. Mice expressing two copies of this conditional knock-out allele are termed Trpa $1^{\mathrm{fl} / \mathrm{fl}}$ mice (Zappia et al., 2016). Two independently-generated lines of Advillin-Cre mice have been described previously (da Silva et al., 2011; Zurborg 
et al., 2011). Heppenstall Advillin-Cre mice, described previously (Zurborg et al., 2011), contain a five copies of an inserted bacterial artificial chromosome (BAC) transgene containing Cre recombinase within the Advillin gene locus and its presumed regulatory elements. The second Advillin-Cre line, Wang Advillin-Cre mice, were described previously (da Silva et al., 2011) and were generated by targeted knock-in of the Cre allele into the second exon of the Advillin gene.

Both lines of the Advillin-Cre mice were crossed with the Trpa $1^{\mathrm{fl} / \mathrm{fl}}$ mice (Zappia et al., 2016) to generate conditional knock-out animals; these Advillin-Cre, Trpa $1^{\mathrm{fl} / \mathrm{fl}}$ mice are referred to here as $A d v^{C r e} \operatorname{Trpa} 1^{\mathrm{fl} / \mathrm{fl}}$ mice. Where applicable, $A d v^{C r e} T r p a 1^{f / f l}$ mice used throughout this manuscript are delineated by the line of Advillin-Cre from which they were generated (Hepp Adv ${ }^{\mathrm{Cre}} \operatorname{Trpa}^{\mathrm{fl} / \mathrm{fl}}$ and Wang $A d v^{\text {Cre }}$ Trpa $1^{\mathrm{fl} / \mathrm{fl}}$ ). Importantly, expression of Cre alone in Advillin-expressing sensory neurons has been previously shown to have no effects on baseline sensory behaviors (Zurborg et al., 2011; Minett et al., 2012). As such, Advillin-Cre-expressing, Trpa $1^{+/+}$mice were used as controls for the conditional knock-out, $A d v^{\mathrm{Cre}} \operatorname{Trpa} 1^{\mathrm{fl} / \mathrm{fl}}$ mice. Control mice from both Hepp and Wang colonies were used; the data were combined as no phenotypic differences were noted. Mating pairs in all cases consisted of a $\mathrm{Cre}^{+}$male crossed with a $\mathrm{Cre}^{-}$female, ensuring Cre transmission only from the male progenitor. Tissues from the appropriate animals were obtained and visualized for cells expressing functional Cre recombinase using an Ai9 fluorescent reporter mouse (tdTomato ${ }^{\text {LSL)}}$, in which tdTomato is only expressed when a loxP-flanked STOP cassette is excised. Lastly, we used global Trpa1 knock-out mice lacking TRPA1 in all tissues (Kwan et al., 2006) as a control.

In all instances, mouse genotype was confirmed by PCR. All methods and procedures were reviewed and approved by the Institutional Animal Care and Use Committee of the Medical College of Wisconsin. Animals were provided food and water ad libitum and housed on a 14/10 h light/dark cycle. Further, animal care adhered to the NIH Guide for the Care and Use of Laboratory Animals.

\section{Animal behavior}

Behavioral tests of mechanical and thermal sensitivity were performed on the glabrous surface of the hindpaw of male and female mice at least eight weeks of age. No differences were noted between sexes, so these data were combined for all datasets. Experimenters were blinded to mouse genotype for all assays. Animals were acclimated to handling by the experimenter and were habituated to each applicable testing apparatus for an hour prior to test day (with one exception, as noted). Additionally, animals were habituated to the testing environment and apparatus for at least an hour on the day of testing.

For assays of mechanical sensitivity, mice were placed in small plexiglass enclosures on top of a wire mesh to allow probing of the plantar hind paw. Mechanical paw withdrawal thresholds were determined from responses to calibrated von Frey filaments (North Coast Medical), calculated using the Up-Down method as described previously (Dixon, 1980; Chaplan et al., 1994). Also, a 3.31 $\mathrm{mN}$ von Frey filament was applied 10 times to the plantar hindpaw, and the frequency of a withdrawal response was determined. Similarly, percent responses to both gentle punctate $(0.7 \mathrm{mN}$ von Frey filament) and dynamic (puffed cotton swab) stimuli were recorded; each stimulus was applied to both hindpaws 10 times, giving at least $30 \mathrm{~s}$ between stimuli. As a test of responsiveness to a noxious stimulus, a 25-gauge spinal needle was applied to the plantar hindpaw 10 times; each response was categorized into one of the following classifications: normal (withdrawal; a brief response), flutter, hold, lick, or no response. Again, the minimum interval between subsequent applications was $1 \mathrm{~min}$, to avoid inducing sensitization. For all behavioral tests of mechanical sensitivity, left and right hindpaw responses were averaged for each animal.

To test heat sensitivity, mice were placed in small plexiglass enclosures on top of a glass plate, and a focal radiant heat source applied to the plantar hindpaw. The response latency to withdraw from the heat stimulus was quantified (Hargreaves et al., 1988). Cold sensitivity was measured using a two-temperature preference assay, consisting of two equally-sized, metal temperature-controlled metal floor plates (AHP1200-HCP, TECA Corp) enclosed within a $13^{\prime \prime} \times 13^{\prime \prime}$ testing chamber. In the 5 -min baseline period, animals were placed in the center of the chamber and allowed to explore freely, in order to test baseline activity and intrinsic chamber preference while both floor plates were held at room temperature $\left(23^{\circ} \mathrm{C}\right)$. During this baseline phase, mice of both genotypes spent equivalent amounts of time on each of the testing chambers when both floor plates were held at $23^{\circ} \mathrm{C}$. For the 5 -min testing phase, the two floor plates were set at $20^{\circ} \mathrm{C}$ and $10^{\circ} \mathrm{C}$, and mice were allowed to explore freely. The amount of time spent on each of the two plates was recorded and compared between genotypes.

\section{Sensory neuron isolation and culture}

Sensory neurons were isolated from bilateral lumbar 1-6 dorsal root ganglia (DRGs) and cultured as follows. Male mice were anesthetized with isoflurane (Midwest Veterinary Supply) and euthanized via decapitation. Lumbar DRGs 1-6 were dissected bilaterally and placed in HBSS (Gibco, ThermoFischer Scientific). After the dissection, the isolated DRGs were transferred to a 50:50 mixture of DMEM and Ham's F12 medium (Gibco). DRGs were next incubated at $37^{\circ} \mathrm{C}$ and $5 \% \mathrm{CO}_{2}$ with $1 \mathrm{mg} / \mathrm{mL}$ collagenase type IV (Sigma) for $40 \mathrm{~min}$, followed by a 45-min incubation with $0.05 \%$ trypsin (Sigma). Following chemical dissociation, the ganglia were washed and resuspended in a complete medium consisting of a 50:50 mixture of DMEM and Ham's F12 medium supplemented with $10 \%$ heat-inactivated horse serum (Thermo Fisher Scientific), $2 \mathrm{mM}$ L-glutamine (Thermo Fisher), 0.5\% glucose (Sigma), and 0.2 Units Penicillin-Streptomycin (Thermo Fisher). The medium contained no added exogenous growth factors. Ganglia were manually triturated using a P1000 and 
Table 1: Statistical tests used within this manuscript

\begin{tabular}{|c|c|c|c|c|}
\hline a & $\begin{array}{l}\text { Data structure } \\
\text { Non-normally distributed }\end{array}$ & $\begin{array}{l}\text { Type of test } \\
\text { Mann-Whitney } U \text { test }\end{array}$ & Comparison & $\begin{array}{l}95 \% \text { confidence interval } \\
0.8792 \text { to } 2.533\end{array}$ \\
\hline b & Non-normally distributed & Mann-Whitney $U$ test & & -1.552 to 1.983 \\
\hline c & Normally distributed & $t$ test & & -32.19 to -12.11 \\
\hline d & Normally distributed & $t$ test & & -21.40 to 11.40 \\
\hline e & Normally distributed & $t$ test & & -21.01 to -6.262 \\
\hline$f$ & Normally distributed & $t$ test & & -21.01 to -6.262 \\
\hline g & Normally distributed & $t$ test & & -23.05 to 7.592 \\
\hline h & Normally distributed & $t$ test & & -37.06 to 11.70 \\
\hline i & Normally distributed & $t$ test & & -6.135 to 5.468 \\
\hline \multirow[t]{6}{*}{ j } & Normally distributed & Two-way ANOVA & & \\
\hline & & Sidak's multiple comparison test & Normal: WT vs $A d v^{C r e} T R P A 1^{\mathrm{fl} / \mathrm{fl}}$ & 2.706 to 15.60 \\
\hline & & Sidak's multiple comparison test & Hold: WT vs $A d v^{C r e} T R P A 1^{f l / f l}$ & -11.95 to 0.9492 \\
\hline & & Sidak's multiple comparison test & Flutter: WT vs $A d v^{C r e} T R P A 1^{\mathrm{fl} / \mathrm{fl}}$ & -10.18 to 2.723 \\
\hline & & Sidak's multiple comparison test & Lick: WT vs $A d v^{C r e} T R P A 1^{\mathrm{fl} / \mathrm{fl}}$ & -6.211 to 6.687 \\
\hline & & Sidak's multiple comparison test & None: WT vs $A d v^{C r e} T R P A 1^{\mathrm{fl} / \mathrm{fl}}$ & -6.616 to 6.283 \\
\hline k & Normally distributed & $t$ test & & -0.4365 to 12.23 \\
\hline I & Normally distributed & $t$ test & & -12.79 to 11.03 \\
\hline $\mathrm{m}$ & Normally distributed & $t$ test & & -0.4637 to 1.700 \\
\hline $\mathrm{n}$ & Normally distributed & $t$ test & & -2.740 to 1.084 \\
\hline \multirow[t]{4}{*}{ o } & Normally distributed & One -way ANOVA & & \\
\hline & Normally distributed & Sidak's multiple comparison test & Exons 22-23: Wang control vs Wang $A d v^{C r e} T R P A 1^{\mathrm{fl} / \mathrm{fl}}$ & 0.3935 to 1.390 \\
\hline & Normally distributed & Sidak's multiple comparison test & Exons 22-23: Hepp control vs Hepp Adv ${ }^{C r e} T R P A 1^{\mathrm{fl} / \mathrm{fl}}$ & 0.1303 to 1.188 \\
\hline & Normally distributed & Sidak's multiple comparison test & Exons 22-23: Hepp Adv ${ }^{C r e} T R P A 1^{\mathrm{fl} / \mathrm{fl}}$ vs Wang $A d v^{C r e} T R P A 1^{\mathrm{fl} / \mathrm{fl}}$ & -0.3397 to 0.7177 \\
\hline \multirow[t]{4}{*}{ p } & Normally distributed & One-way ANOVA & & \\
\hline & Normally distributed & Sidak's multiple comparison test & Exons 23-24: Wang control vs Wang $A d v^{C r e} T R P A 1^{\mathrm{fl} / \mathrm{fl}}$ & 0.2601 to 1.200 \\
\hline & Normally distributed & Sidak's multiple comparison test & Exons 23-24: Hepp control vs Hepp Adv ${ }^{C r e} T R P A 1^{\mathrm{fl} / \mathrm{fl}}$ & 0.1235 to 1.063 \\
\hline & Normally distributed & Sidak's multiple comparison test & Exons 23-24: Hepp Adv ${ }^{C r e} T R P A 1^{\mathrm{fl} / \mathrm{fl}}$ vs Wang $A d v^{C r e} T R P A 1^{\mathrm{fl} / \mathrm{fl}}$ & -0.3632 to 0.5765 \\
\hline q & Normally distributed & $\chi^{2} \mathrm{w} /$ Yates correction & Odds ratio, confidence interval reported & 1.092 to 1.671 \\
\hline r & Normally distributed & Fisher's exact test & Odds ratio, confidence interval reported & 5.460 to 11.06 \\
\hline s & Normally distributed & $t$ test & & -29.71 to 54.57 \\
\hline $\mathrm{t}$ & Normally distributed & Fisher's exact test & Odds ratio, confidence interval reported & 0.5011 to 1.378 \\
\hline u & Normally distributed & $t$ test & & -57.15 to 126.7 \\
\hline v & Normally distributed & Fisher's exact test & Odds ratio, confidence interval reported & 0.5210 to 0.9708 \\
\hline w & Normally distributed & $t$ test & & -37.03 to 69.37 \\
\hline$x$ & Non-normally distributed & Kruskal-Wallis test & Dunn's post hoc multiple comparison test does not generate co & nfidence intervals \\
\hline \multirow[t]{4}{*}{ y } & Normally distributed & One -way ANOVA & & \\
\hline & & Sidak's multiple comparison test & WT vs $A d v^{C r e} T R P A 1^{f l / f l}$ & 0.5382 to 20.57 \\
\hline & & Sidak's multiple comparison test & WT vs TRPA1 KO & 17.76 to 37.80 \\
\hline & & Sidak's multiple comparison test & $A d v^{C r e} T R P A 1^{\mathrm{fl} / \mathrm{fl}}$ vs TRPA1 KO & 8.262 to 26.18 \\
\hline
\end{tabular}

P200 pipettor, and isolated neurons were plated onto glass coverslips coated with laminin (Sigma).

\section{Calcium imaging}

Calcium imaging was performed in the presence of a synthetic extracellular normal HEPES (ENH) buffer containing: $150 \mathrm{mM} \mathrm{NaCl}, 10 \mathrm{mM}$ HEPES, $8 \mathrm{mM}$ glucose, 5.6 $\mathrm{mM} \mathrm{KCl}, 2 \mathrm{mM} \mathrm{CaCl}_{2}$, and $1 \mathrm{mM} \mathrm{MgCl}_{2}$ (all from Sigma). After 18-28 $\mathrm{h}$ in culture, isolated cells were incubated for $45 \mathrm{~min}$ in $2 \% \mathrm{BSA}$ and $2.5-\mu \mathrm{l} / \mathrm{mL}$ Fura-2 AM (Invitrogen), a dual-wavelength fluorescent calcium indicator, and washed for $30 \mathrm{~min}$ in ENH. Coverslips were then superfused with buffer at $6 \mathrm{~mL} / \mathrm{min}$ and fluorescence images captured using a cCMOS camera (Zyla; Andor Technology LTD) using NIS Elements (Nikon Instruments) software. Fluorescence images were captured at both $340 \mathrm{~nm}$ $\left(\mathrm{Ca}^{2+}\right.$ bound Fura-2) and $380 \mathrm{~nm}$ (unbound Fura-2). A $\geq 20 \%$ increase in 340 to $380 \mathrm{~nm}$ ratio from baseline measures was considered a response to a given stimulus, indicating an increase in intracellular calcium.

To assess functionality of TRPA1 expressed in sensory neurons, we used cinnamaldehyde (CINN; Sigma) as a TRPA1 agonist (Jordt et al., 2004), as it is more selective than allyl isothiocyanate, which can also activate TRPV1 (Everaerts et al., 2011). Following baseline measurements, coverslips were superfused with either the TRPA1-specific agonist, CINN (100 $\mu \mathrm{M})$ for 3 min; a TRPV1 agonist, capsaicin (100 nM; CAP; Fluka, Sigma; Caterina, 2000) for $1 \mathrm{~min}$; or both CINN followed by a 2-min wash, and then CAP. Following these stimuli, a $50 \mathrm{mM} \mathrm{KCl}(\mathrm{K}+)$ solution was superfused to determine neuronal viability. Since the majority of TRPA1-expressing neurons are small-diameter neurons when observed via immunohistochemistry (Story et al., 2003), in situ hybridization (Kobayashi et al., 2005), or by using functional responsiveness in calcium imaging (Barabas et al., 2012), small-diameter neurons were the focus of this study. Imaging was not restricted to cells expressing Cre recombinase; all viable, small-diameter neurons within the imaging frame were used. Neurons were considered small if the cell body diameter was less than $27 \mu \mathrm{m}$; in mouse, this population typically corresponds to $\mathrm{C}$ fiber type somata (Dirajlal et al., 2003).

\section{Fluorescence imaging}

Sensory neurons were isolated from lumbar DRGs and cultured as above; DRGs were obtained from $A d v^{\text {Cre }}$ tdTomato ${ }^{\mathrm{LSL}}$ mice. The proportion of cultured DRG neurons expressing fluorescent tdTomato was calculated for Adv ${ }^{C r e}$ tdTomato mice from both the Wang and Heppenstall colonies. Independently, DRGs from Advillin-Cre mice crossed with a reporter mouse expressing EGFP-tagged Cas9 were also isolated, sectioned, and visualized. 
A

Mechanical Threshold

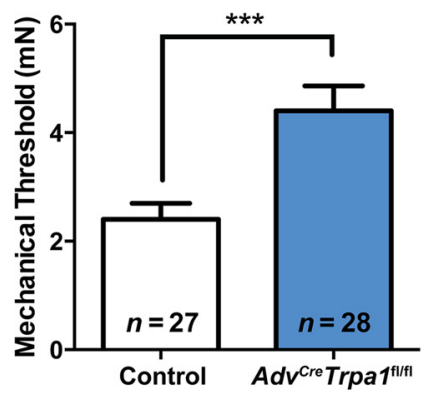

C

Repeated Mechanical Stimuli $3.31 \mathrm{mN}$

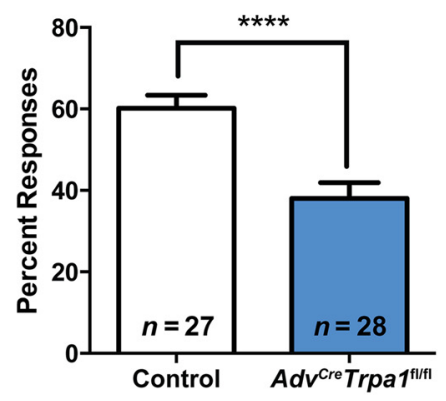

E

Punctate Light Touch $0.7 \mathrm{mN}$

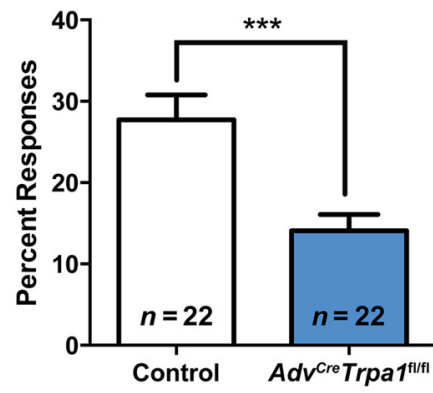

G

Dynamic Cotton

Stimulation

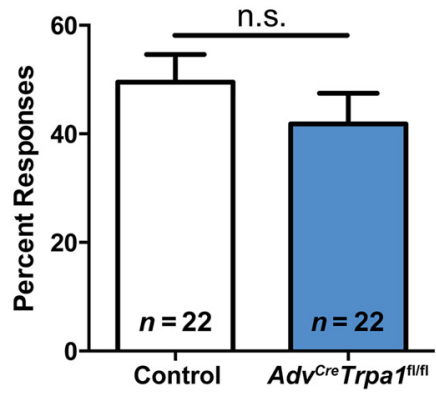

B

Mechanical Threshold

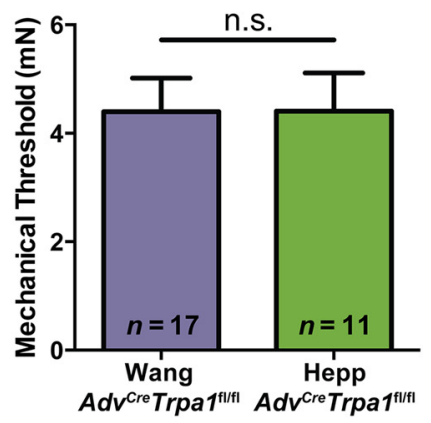

D

Repeated Mechanical Stimuli $3.31 \mathrm{mN}$

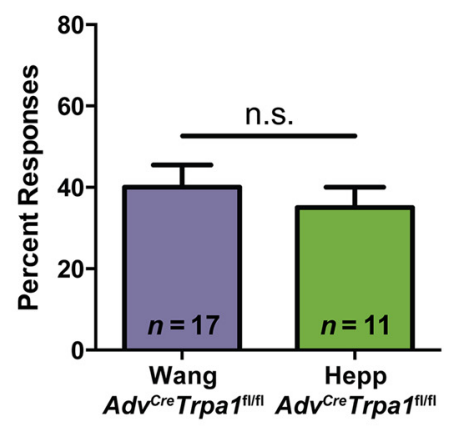

$\mathbf{F}$

Punctate Light Touch

$0.7 \mathrm{mN}$

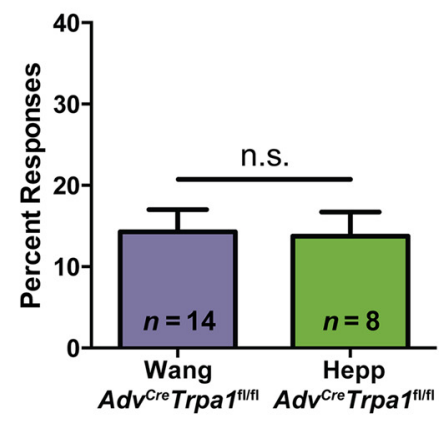

H

Dynamic Cotton

Stimulation

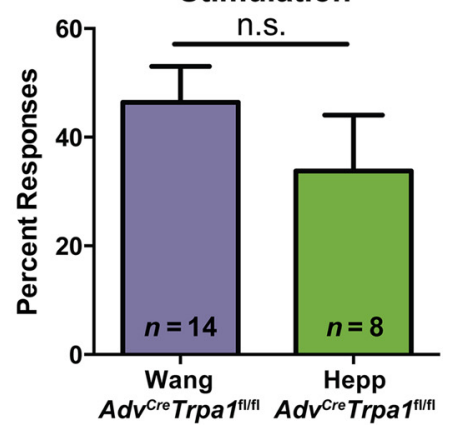

Figure 1. Deletion of TRPA1 from sensory neurons impairs mechanosensory behaviors. $\boldsymbol{A}$, In $A d v^{\mathrm{Cre}} \operatorname{Trpa}^{\mathrm{fl} / \mathrm{fl}}$ animals, paw withdrawal thresholds were significantly elevated compared to controls. In the first panel, Adv ${ }^{\mathrm{Cre}} \mathrm{Trpa}^{\mathrm{f}^{\mathrm{flfl}}}$ animals are a combination of animals 


\section{continued}

from both Advillin-Cre lines. B, Paw withdrawal thresholds in $A d v^{C r e}$ Trpa $1^{\mathrm{fl} / \mathrm{fl}}$ animals from the Wang and Heppenstall Advillin-Cre lines were similar. $\mathbf{C}$, Behavioral mechanical sensitivity, measured by repeated stimulation of the glabrous hindpaw with a $3.31 \mathrm{mN}$ stimulus, was also impaired in the $A d v^{C r e} \operatorname{Trpa}^{\mathrm{fl} / \mathrm{fl}}$ animals. $\boldsymbol{D}$. Mechanical sensitivity to a repeated $3.31 \mathrm{mN}$ stimulus was equivalent between $A d v^{C r e} T r p a 1^{f l / f l}$ animals derived from each of the Advillin-Cre lines. E, Sensitivity to a light touch (0.7 mN) stimulus was impaired in $A d v^{C r e} T r p a 1^{\mathrm{fl} / \mathrm{fl}}$ mice, and this impairment was evident in both Wang and Heppenstall Advillin-Cre lines (F). G, $\boldsymbol{H}$, Behavioral responsiveness to a dynamic light touch stimulus was not impacted by loss of sensory neuron TRPA1. The number of animals per group is denoted within each panel $(\boldsymbol{A}-\boldsymbol{- H})$ of the figure. $* * p<0.01 ; * * * p<0.001$, n.s. denotes a nonsignificant comparison. Male and females were combined for all datasets because no differences were noted between the sexes.

\section{Gene expression studies}

Lumbar DRGs (1-6 bilaterally) were collected, and mRNA was isolated using TRIzol and the PureLink RNA Micro kit (Life Technologies). mRNA was reverse transcribed using the Superscript VILO master mix (Thermo Fisher Scientific), which includes both random hexamers and oligo dT for CDNA synthesis initiation. Real-time PCR was performed on a Mastercycler ep Realplex ${ }^{2}$ thermal cycler (Eppendorf) using TaqMan primers and probes (Life Technologies) for Trpa1 and Gapdh. The pore region of Trpa1 was amplified and detected using two TaqMan assays: Mm01227447_m1 to detect exons 23-24 and Mm00625259_g1 for exons 22-23.

\section{Data analysis}

Paw withdrawal thresholds were compared between two groups using nonparametric Mann-Whitney $U$ tests and among three groups using a Kruskal-Wallis test. All other behavioral assays were analyzed using parametric $t$ tests for two groups, or a one-way ANOVA for three groups, with Sidak post hoc analysis. In calcium imaging experiments, the proportion of neurons responding to a given stimulus was compared between genotypes using a Fisher's exact test, and the average magnitude of responses was compared using a Student's $t$ test. Gene expression studies were analyzed using one-way ANOVA with Sidak post hoc. Summarized data are reported as mean \pm SEM. All data were analyzed using Prism 6 software (GraphPad), with an $\alpha$ of 0.05 set a priori. All statistical tests used, and resultant confidence intervals, are presented in Table 1.

\section{Results}

\section{Selective deficiency of TRPA1 within sensory neurons impairs baseline mechanical behavioral sensitivity}

In a test of mechanical sensitivity, $A d v^{\mathrm{Cre}} \operatorname{Trpa}^{\mathrm{fl} / \mathrm{fl} \mathrm{l}}$ (combined from both Wang and Hepp Cre lines) mice displayed a nearly two-fold increase in paw withdrawal thresholds compared to controls (Fig. $1 A^{\mathrm{a}}$ ). Importantly, similar impairments in mechanosensory phenotype were observed in both the Wang and Heppenstall Advillin-Cre lines $\left(\right.$ Fig. $\left.1 B^{\text {b }}\right)$. Similarly, there were no differences observed between controls $\left(A d v^{C r e} \operatorname{Trpa~}^{+/+}\right.$) from the Wang and Hepp lines and therefore, they were combined for all data sets. Adv ${ }^{C r e}$ Trpa ${ }^{1 / / f l}$ mice also displayed reduced response frequencies when probed repeatedly with a 3.31 $\mathrm{mN}$ filament; again, there was a clear phenotypic overlap between the two Advillin-Cre lines, as there were no differences between $A d v^{\mathrm{Cre}} \mathrm{Trpa}^{\mathrm{fl} / \mathrm{fl}}$ from the Wang and Hepp lines (Fig. $1 C^{\mathrm{c}}, D^{\mathrm{d}}$ ). Additionally, there were no clear sex differences in any of these behavioral measures, so these data include combined outcomes from both sexes.

Responses to punctate light touch were reduced by $49 \%$ in $A d v^{C r e} \operatorname{Trpa}^{\mathrm{fl} / \mathrm{fl} \mathrm{l}}$ mice (Fig. $1 E^{\mathrm{e}}, \mathrm{F}^{\mathrm{f}}$ ). In contrast, responses to a dynamic light touch stimulus (cotton swab test) were not different between Adv ${ }^{\mathrm{Cre}} \operatorname{Trpa}^{\mathrm{fl} / \mathrm{fl}}$ and control mice (Fig. $1 G^{\mathrm{g}}, H^{\mathrm{h}}$ ).

We next tested for sensitivity to a noxious mechanical stimulus using a needle test. Interestingly, following application of a spinal needle to the plantar paw, we observed no deficit in $A d v^{\text {Cre }} \operatorname{Trpa1}^{\mathrm{fl} / \mathrm{fl}}$ mice compared to
A

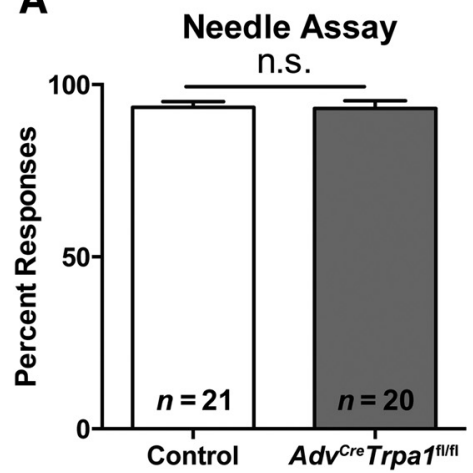

B

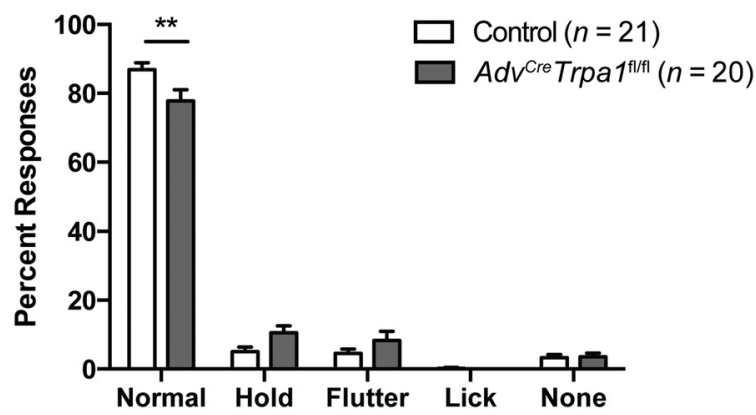

Figure 2. $A d v^{C r e} \operatorname{Trpa}^{\mathrm{fl} / \mathrm{fl}}$ mice exhibit altered responsiveness to a noxious stimulus. $\boldsymbol{A}$, Both control and $A d v^{\mathrm{Cre}} T r p a 1^{\mathrm{fl} / \mathrm{fl}}$ mice responded to a needle stimulus $93 \%$ of the time when all response types were included. $\boldsymbol{B}$, When responses to the needle stimulus were further categorized, $A d v^{C r e} T_{r p a} 1^{\mathrm{fl} / \mathrm{fl}}$ animals exhibited a decrease in the percentage of normal (brief withdrawal) responses. Mice in this figure are all from the Wang Advillin-Cre line. The number of mice per genotype is denoted within the figure. $* * p<0.01$. 


\section{A}

Thermal Preference - Cold

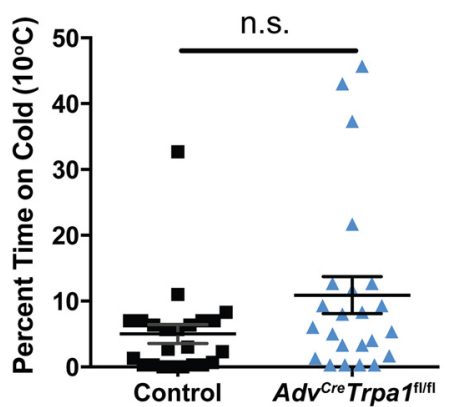

C

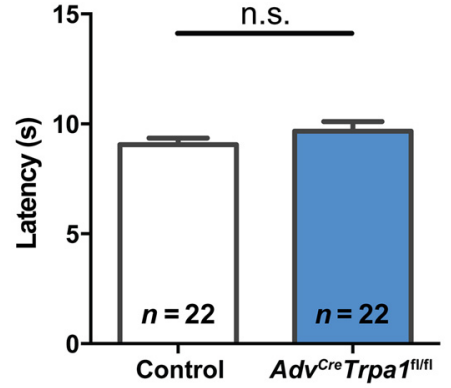

B

Thermal Preference - Cold

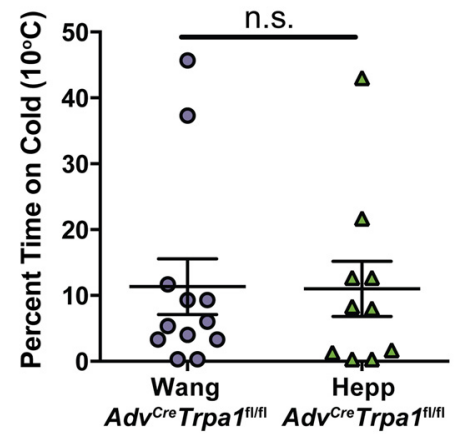

D

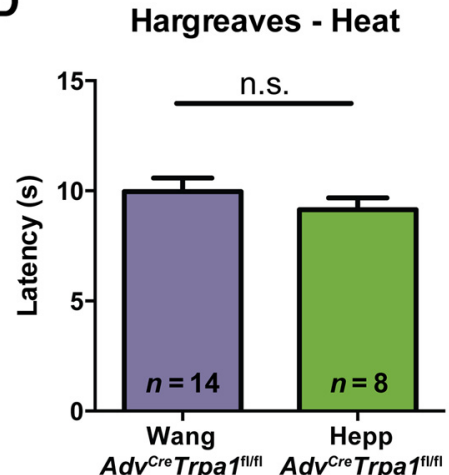

Figure 3. Thermosensory behaviors were not impacted by knock-out of TRPA1 from sensory neurons in naïve mice. $\boldsymbol{A}$, $\boldsymbol{B}$, As measured in a thermal preference assay, percent time spent on the colder of two plates $\left(10^{\circ} \mathrm{C}\right.$ or $\left.20^{\circ} \mathrm{C}\right)$ was similar between control $(n=22)$ and $A d v^{C r e} T_{r p a} 1^{\mathrm{fl} / f l}$ animals $(n=22$ total; $n=14$ Wang, $n=8$ Hepp). $\boldsymbol{C}, \boldsymbol{D}$, Latency to paw withdrawal from a heat stimulus was not impaired in $A d v^{C r e} T_{r p a 1}{ }^{\mathrm{fl} / \mathrm{fl}}$ mice. n.s. denotes no significant difference.

controls (Fig. 2A'). However, upon closer inspection, we observed that $A d v^{C r e} \operatorname{Trpa}^{\mathrm{fl} / \mathrm{fl}}$ mice exhibited a significant decrease in the percentage of normal responses to the stimulus and instead tended to have an increased propensity for holding their paw in the air or briefly fluttering the paw (Fig. $2 B^{j}$ ). Responses such as licking, holding, and fluttering of the hindpaw in response to a stimulus have previously been described as hyperalgesic-type responses (Hogan et al., 2004). However, anecdotally the Adv ${ }^{\mathrm{Cre}} \operatorname{Trpa}^{\mathrm{fl} / \mathrm{ll}}$ mice that held their paw up in this assay actually appeared uninterested, and these responses were unlike those of mice with paw inflammation, where it appears that the injured paw is being withheld and protected from further probing by the experimenter for example, by placing their paw out of reach on the cage wall, and often appearing simultaneously agitated. However, Adv ${ }^{C r e}$ Trpa ${ }^{1 / / f l}$ mice rarely displayed these more exaggerated forms of holding their paw away from the experimenter.

\section{Sensory neuron-specific knock-out of TRPA1 does not impair behavioral responses to cold or heat}

To test for impairment in cold sensitivity, we used a two-temperature preference assay, in which the floor of the testing chamber was divided in half into a mildly cool $20^{\circ} \mathrm{C}$ portion and a more noxious $10^{\circ} \mathrm{C}$ cold plate. Importantly, in this assay, behavioral cold aversion was unaltered in the Adv Cre Trpa $1^{\mathrm{fl} / \mathrm{fl}}$ mice compared to controls, as $A d v^{C r e} \operatorname{Trpa}^{\mathrm{fl} / \mathrm{fl}}$ and controls spent an equivalent amount of time on the $10^{\circ} \mathrm{C}$ cold plate (Fig. $\left.3 A^{\mathrm{k}}, B^{\prime}\right)$. Interestingly, three of the $A d v^{\mathrm{Cre}} \operatorname{Trpa}^{1 / \mathrm{fl} \mathrm{fl}}$ animals and one control mouse spent noticeably more time on the cold plate compared to the majority of the animals, implying interanimal variability independent of genotype. Despite this variability, it was clear that $A d v^{C r e} \operatorname{Trpa} 1^{1 / / f l}$ mice retained the capacity to sense cold stimulation. Locomotor activity and exploratory drive was not impaired in the $A d v^{\mathrm{Cre}}{ }_{\mathrm{Trpa}} 1^{\mathrm{fl} / \mathrm{fl}}$ mice, as these mice crossed between the two plates at the chamber midline a similar number of times during the baseline phase of cold testing (data not shown).

We next tested whether the $A d v^{\mathrm{Cre}} \operatorname{Trpa}^{\mathrm{fl} / \mathrm{fl}}$ mice displayed any deficit in behavioral responses to thermal stimuli. Response latencies to a heat stimulus were not different between $A d v^{\mathrm{Cre}} \mathrm{Trpa}^{\mathrm{fl} / \mathrm{fl}}$ and control mice (Fig. $\left.3 C^{\mathrm{m}}\right) . A d v^{\mathrm{Cre}}$ Trpa $1^{\mathrm{fl} / \mathrm{fl}}$ mice from the Wang and Heppenstall Cre lines had similar heat response latencies, and both mouse lines were similar to control mice (Fig. $\left.3 D^{\mathrm{n}}\right)$.

\section{Confirmation of Cre expression and deletion of Trpa1 in sensory neurons in Advillin-Cre+ mice}

To confirm that Cre recombinase was functional in DRGs, we quantified the amount of Trpa1 mRNA isolated from whole DRGs from control and Adv ${ }^{\mathrm{Cre}} \mathrm{Trpa} 1^{\mathrm{fl} / \mathrm{fl}}$ mice from each of the Cre lines. Trpa1 transcript was significantly decreased by the conditional knock-out in both mouse lines (Fig. $4 A^{\mathrm{o}, \mathrm{p}}$ ). Here, there was a trend toward increased reduction in Trpa1 transcript in the Wang Cre 
A

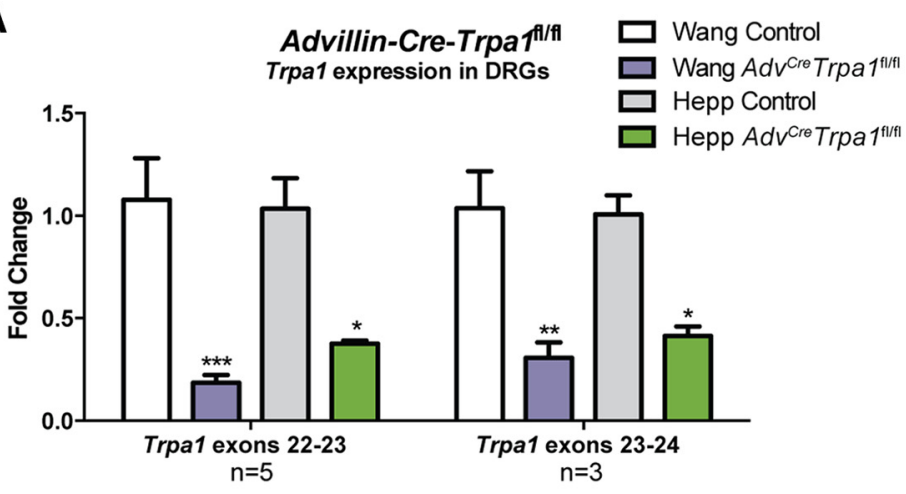

B

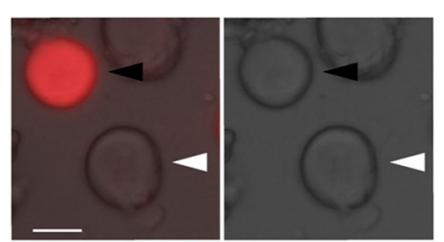

D

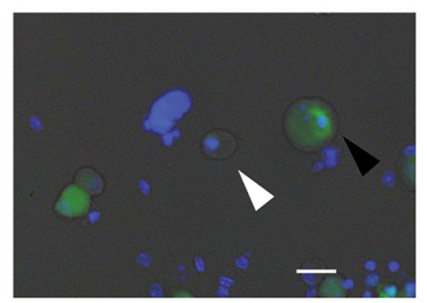

F

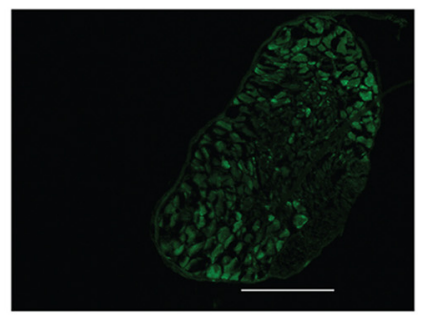

H

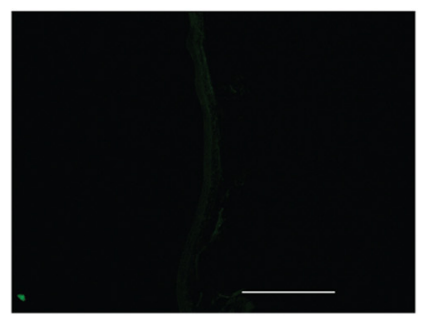

C

Advillin-Cre-tdTomato ${ }^{\text {LSL }}$

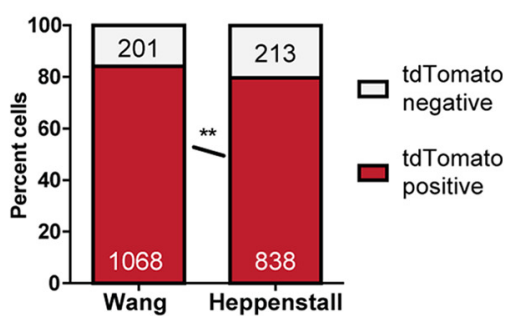

E

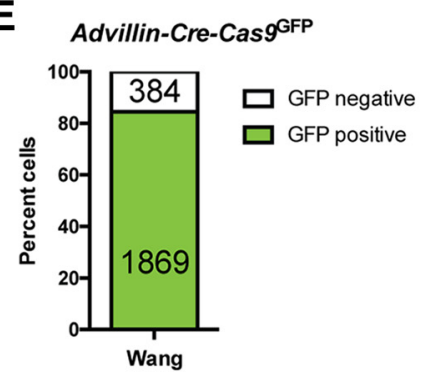

G

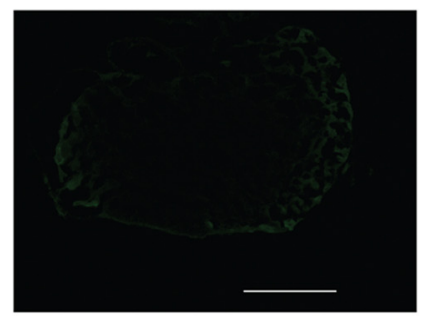

I

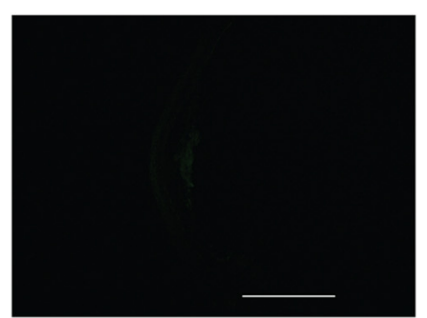

Figure 4. Advillin-Cre drivers induce functional Cre recombinase expression in sensory neurons. $\boldsymbol{A}$, RT-PCR of DRGs isolated from control and $A d v^{C r e}$ Trpa $^{\mathrm{fl} / \mathrm{fl}}$ animals showed a pronounced reduction in Trpa1 mRNA in Adv ${ }^{C r e}$ Trpa $1^{\mathrm{fl} / \mathrm{fl}}$ animals. Two primer sets for Trpa1 were used, each targeting the pore region of TRPA1. There was no significant difference comparing the Adv ${ }^{\mathrm{Cre}} T r p a{ }^{\mathrm{fl} / \mathrm{fl}}$ mice from the Wang and Hepp lines. Each bar represents results from three to five animals, each sample run in duplicate $(n=3$ animals per genotype for exons 22-23, and $n=5$ animals per genotype for exons 23-24). B, Example of a Cre-negative, tdTomato-negative neuron (white arrowhead), and a Cre-positive, tdTomato-positive neuron (black arrowhead) from cultured Adv ${ }^{\text {Cre }}$ Trpa ${ }^{\text {fl/fl }}$ DRGs. On left is overlay of brightfield and fluorescent image. Scale bar, $20 \mu \mathrm{m}$. C, Sensory neurons isolated and cultured from Wang Advillin-Cre 
continued

reporter mice showed a slight but significant increase in the proportion of reporter-positive neurons compared to the Heppenstall Advillin-Cre line. Numbers represent the total number of tdTomato + and tdTomato- neurons counted. $\boldsymbol{D}$, Example Cre+ (black arrowhead) and Cre- (white arrowhead) from Advillin-Cre-Cas9 ${ }^{G F P}$ mice, expressing an EGFP-tagged protein (Cas9) in the presence of Cre. Scale bar, $10 \mu \mathrm{m}$. E. A total of $84.4 \%$ of sensory neurons from Wang Advillin-Cre-Cas9GFP DRGs were GFP-positive. $\boldsymbol{F}$, Fluorescence image of sectioned lumbar DRG isolated from an Advillin-Cre-Cas9 animal. Scale bar, $50 \mu \mathrm{m}$. G, Fluorescent image of sectioned lumbar DRG from Cre-negative mouse. Scale bar, $50 \mu \mathrm{m}$. $\boldsymbol{H}, \boldsymbol{I}$, Fluorescent images of sectioned glabrous hindpaw skin from Advillin-Cre-Cas9 $^{G F P}(\boldsymbol{H})$ and Cre-negative-Cas9 ${ }^{G F P}(I)$ mice. Scale bar, $50 \mu \mathrm{m}$. $* p<0.05 ; * * p<0.01 ; * * * p<0.001$, n.s. denotes a nonsignificant comparison.

line than in the Heppenstall line, although no significant difference was detected. Results were similar between two PCR primer-probe sets, both targeting the poreencoding region of the gene. This finding suggests deletion of Trpa1 within sensory neurons of the Adv ${ }^{C r e} \operatorname{Trpa} 1^{\text {fl/fl }}$ mice.

We concurrently isolated and cultured neurons from $A d v^{C r e}$ tdTomato reporter mice in order to visualize the proportion of cells expressing functional Cre. In the Advillin-Cre DRGs, approximately $80 \%$ of cultured neurons (all diameters included) were positive for tdTomato fluorescence (Fig. $4 B, C^{9}$ ), indicative of Cre activity in those cells. In animals from the Wang Advillin-Cre line, $84.2 \%$ of neurons were fluorescent, while only $79.8 \%$ of neurons from the Heppenstall Advillin-Cre line were fluorescent. Another reporter line (Cas9-GFP) was used to visualize $\mathrm{Cre}^{+}$neurons in intact DRG. We first confirmed that $84.4 \%$ of isolated neurons from this reporter line (Wang) expressed GFP, indicating active Cre recombinase (Fig. $4 D, E$ ). Next, we show a similar proportion of $\mathrm{Cre}^{+}$neurons in sectioned Advillin-Cre-Cas9GFP DRGs (Fig. 4F). Importantly, this Cre activity was not observed in Cre- DRG sections (Fig. 4G), nor was Cre activity present in either Advillin-Cre ${ }^{+}$or $\mathrm{Cre}^{-}$skin sections (Fig. $4 \mathrm{H}, \mathrm{I}$ ) or spinal cord sections (data not shown).

\section{Functional loss of TRPA1 within sensory neurons}

To more directly address the functional effect of the conditional knock-out on sensory neurons, we used calcium imaging to assess the responsiveness of isolated sensory neurons to the TRPA1 agonist, cinnamaldehyde (CINN). Given the broad phenotypic overlap between the Wang and Heppenstall lines, and because there was increased tdTomato reporter expression in the Wang Advillin-Cre line, imaging was only performed on sensory neurons from the Wang $A d v^{C r e} T_{r p a} 1^{\mathrm{fl} / \mathrm{fl}}$ animals. Smalldiameter sensory neurons isolated from Wang Adv ${ }^{\mathrm{Cre}}$ Trpa $1^{\mathrm{fl} / \mathrm{fl}}$ animals were much less likely to respond ( $\geq 20 \%$ over baseline) to $100 \mu \mathrm{M}$ CINN compared to control neurons (Fig. $5 A, B^{\prime}$ ). Importantly, the conditional knock-out line displayed a five-fold reduction in the percentage of neurons responding to CINN compared to control neurons, corresponding to the expression of Cre in $80 \%$ of sensory neurons (Fig. 4B). In the $8 \%$ of neurons that remained responsive, the magnitude of calcium influx remained unchanged compared to control responses (Fig. $5 C^{\mathrm{s}}$ ). Analysis of CINN responsiveness was limited to smalldiameter neurons but was not restricted by expression of TRPV1. In a separate experiment, there was no impairment in responsiveness to the TRPV1 agonist, capsaicin, as $42-46 \%$ of small neurons from either cohort responded (Fig. $5 D, E^{\mathrm{t}}, F^{\mathrm{u}}$ ). Some coverslips were treated first with CINN and then capsaicin; interestingly, among cells preexposed to CINN administration, there was a slightly increased prevalence of neurons responding to capsaicin in the $A d v^{C r e}$ Trpa $1^{\mathrm{fl} / \mathrm{fl}}$ mice (Fig. $5 G, H^{\mathrm{v}}, \mathrm{I}^{\mathrm{W}}$ ).

\section{Conditional TRPA1 knock-out mice display incomplete disruption of mechanosensory ability}

Given the incomplete elimination of TRPA1 from the sensory neurons of the $A d v^{C r e} T r p a 1^{\mathrm{fl} / \mathrm{fl}}$ animals (approximately $80 \%$, both at the level of mRNA and functionally via calcium imaging), we next compared the behavioral mechanosensory deficit of the $A d v^{C r e} T r p a 1^{\mathrm{fl} / \mathrm{fl}}$ to that of global TRPA1 knock-out mice (Kwan et al., 2006). Given the restriction of TRPA1 deletion from only sensory neurons, we would not anticipate sensory phenotypes beyond those identified in global TRPA1 knock-outs. Here, we observed that global TRPA1 knock-out mice displayed a greater deficit in mechanosensory behaviors than the Adv Cre Trpa $1^{\mathrm{fl} / \mathrm{fl}}$ mice (Fig. $6^{\mathrm{x}, y}$ ), although both $A d v^{\mathrm{Cre}} \mathrm{Trpa}^{\mathrm{fl} / \mathrm{fl}}$ and global TRPA1 mice displayed elevated paw withdrawal thresholds (Fig. 6A) and decreased responsiveness to a $3.31 \mathrm{mN}$ stimulus (Fig. 6B) compared to controls.

\section{Discussion}

These data demonstrate that sensory neuron-specific knock-out of TRPA1 induces clear mechanosensory deficits, an observation which is in strong concordance with previous findings in global TRPA1 knock-out mice (Kwan et al., 2006), while aversion to noxious cold using a behavioral preference assay remained intact. These results distinctly implicate sensory-neuron TRPA1 in baseline mechanical sensitivity in vivo. Further studies utilizing this mouse line will be valuable in addressing other sensory neuron-specific functions of TRPA1.

Our findings of only partial mechanosensory impairment compared to global knock-out mice are in line with the incomplete ablation of TRPA1 from all sensory neurons, as evidenced by both gene expression studies and functional assessment via calcium imaging. However, this is understandable given that Cre-mediated recombination under the Advillin promoter was only observed in $80 \%$ of cultured sensory neurons, and a corresponding $80 \%$ reduction in CINN-responsive neurons in the Adv ${ }^{\mathrm{Cre}} \operatorname{Trpa} 1^{\mathrm{fl} / \mathrm{fl}}$ animals. That is, the small amount of remaining TRPA1 within a subpopulation $(20 \%)$ of sensory neurons may largely mediate this apparent incomplete deficit when compared to the global knock-outs. Similarly, others have shown an incomplete deficit in proprioception when ab- 
A
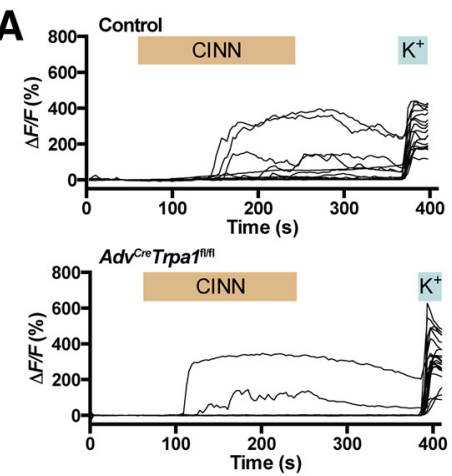

D
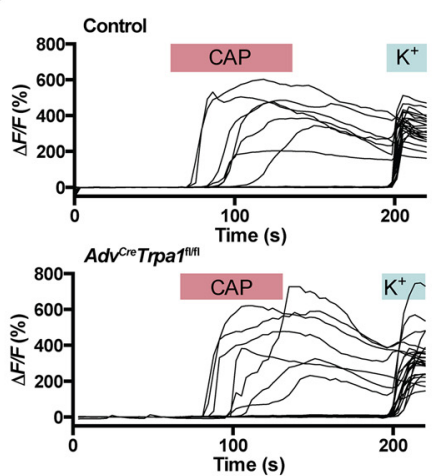

G
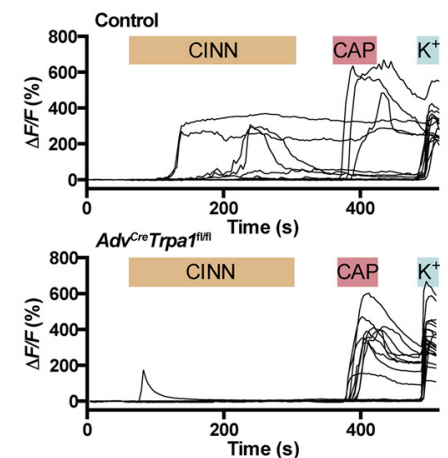

B

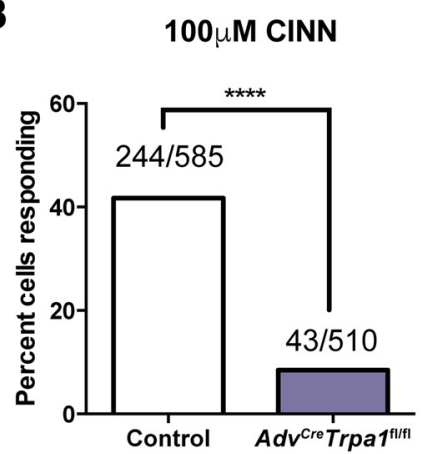

E

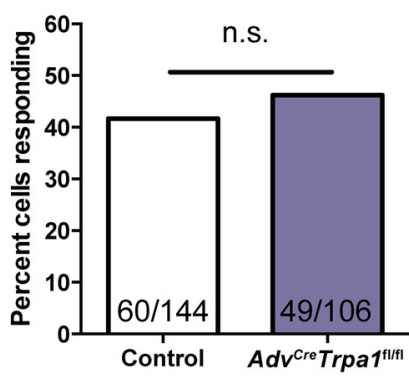

H

100 nM Capsaicin (after $100 \mu \mathrm{M}$ CINN)

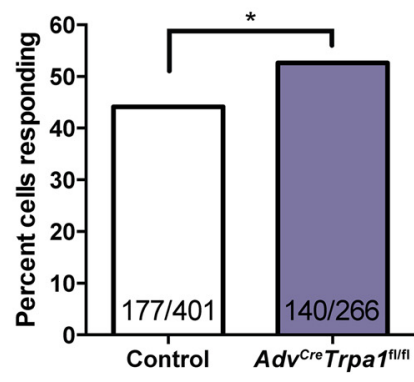

C

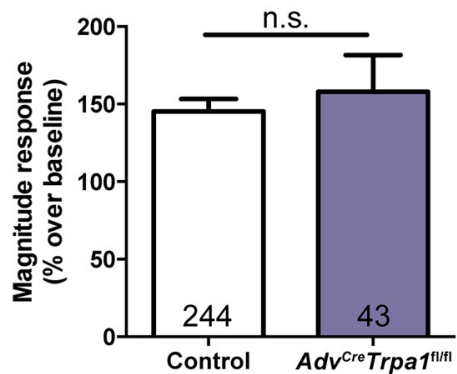

$\mathbf{F}$

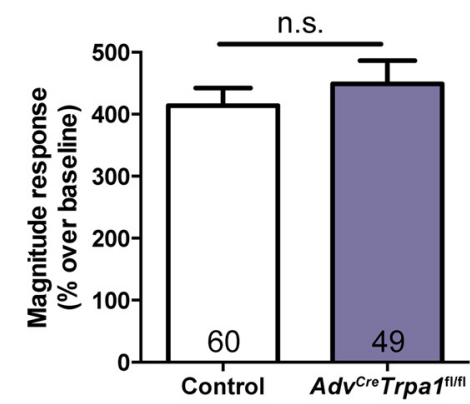

I

100 nM Capsaicin (after $100 \mu \mathrm{M}$ CINN)

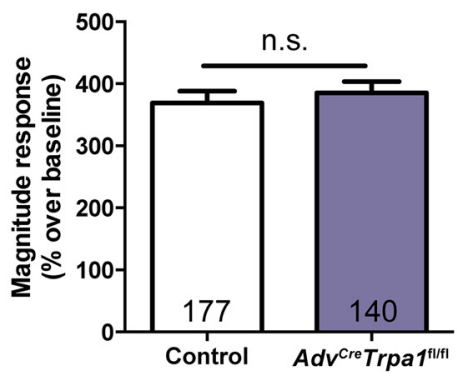

Figure 5. Calcium imaging of small-diameter control and $A d v^{\mathrm{Cre}} \operatorname{Trpa}^{\mathrm{fl} / \mathrm{fl}}$ sensory neurons indicates significant TRPA1-mediated functional deficits. Sensory neurons tested via calcium imaging were all from the Wang Advillin-Cre line. $\boldsymbol{A}$, Example traces of increasing intracellular calcium in several individual neurons following application of $100 \mu \mathrm{M}$ cinnamaldehyde (CINN). $\Delta F / F$ (\%) indicates the percent increase of Fura-2 $340 / 380 \mathrm{~nm}$ fluorescence normalized to baseline for each individual cell. $\mathrm{K}+$ indicates 50 mM $\mathrm{KCL}$ used to depolarize neurons. $\boldsymbol{B}$, The proportion of sensory neurons responding to $100 \mu \mathrm{M}$ CINN is significantly decreased in $A d v^{C r e}$ Trpa ${ }^{\mathrm{fl} / \mathrm{fl}}$ mice. $N$ listed on the figure indicate the number of cells responding to the stimulus over the number of cells tested. This experiment was replicated twice for each genotype (two animals per genotype); results were combined. $\boldsymbol{C}$, Among neurons respond to $100 \mu \mathrm{M}$ CINN, cells from control and $A d v^{C r e}$ Trpa $1^{\mathrm{fl} / \mathrm{fl}}$ mice had a similar magnitude calcium response. $\boldsymbol{D}$, Sample traces of Fura-2 fluorescence in control and $A d v^{C r e}$ Trpa $^{\text {fl/fl }}$ small-diameter neurons after stimulation with $100 \mathrm{nM}$ capsaicin (CAP). $\boldsymbol{E}$, $\boldsymbol{F}$, When stimulated with $100 \mathrm{nM}$ capsaicin, neurons from control and $A d v^{C r e} T r p a 1^{f / / f l}$ mice responded with a similar frequency $(E)$ and magnitude of response; two animals per genotype $(\boldsymbol{F})$. G. Example traces of $\Delta F / F(\%)$ (percent increase in Fura-2 fluorescence over baseline) in control and $A d v^{C r e} T r p a 1^{\mathrm{fl} / \mathrm{fl}}$ exposed sequentially to both $100 \mu \mathrm{M}$ CINN and $100 \mathrm{nM}$ capsaicin. $\boldsymbol{H}$, Following administration of $100 \mu \mathrm{M}$ CINN, sensory neurons from Adv Cre Trpa $1^{\mathrm{fl} / \mathrm{fl}}$ mice exhibited a slightly although significantly increased proportion of responsiveness (two animals per genotype). I, Even after $100 \mu \mathrm{M}$ CINN exposure, sensory neurons from control and Adv ${ }^{C r e}$ Trpa $1^{\mathrm{fl} / \mathrm{fl}}$ mice responded with equivalent magnitude of calcium responses to a $100 \mathrm{nM}$ capsaicin stimulus. $* p<0.05 ; * * * * p<0.0001$, and n.s. denotes a nonsignificant comparison.

lating Piezo2 using an Advillin-CreERT2 driver, while Cre drivers that were more specific to proprioceptive populations of neurons produced a more severe deficit (Woo et al., 2014). Nonetheless, these data demarcate a clear role for sensory neuron expression of TRPA1 in mechanosensation.

These findings also indicate that sensory neuron expression of TRPA1 is not required for behavioral cold 
A

Mechanical Threshold

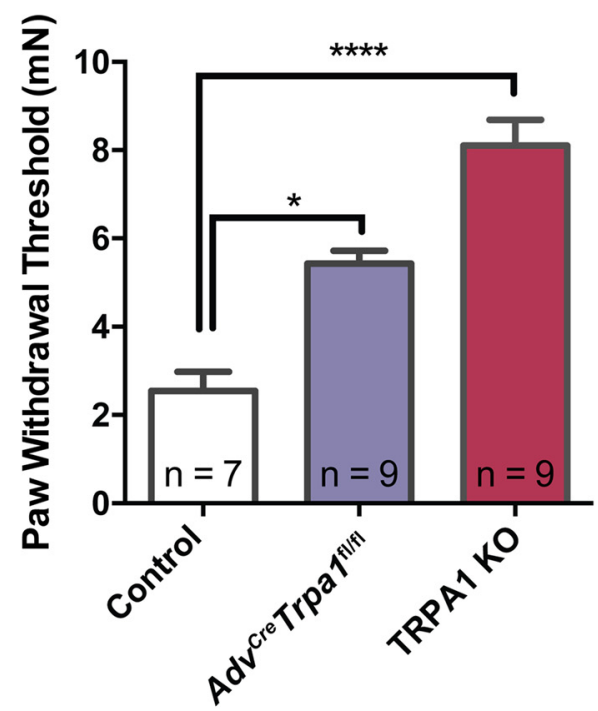

B

\section{Repeated Mechanical Stimuli} $3.31 \mathrm{mN}$

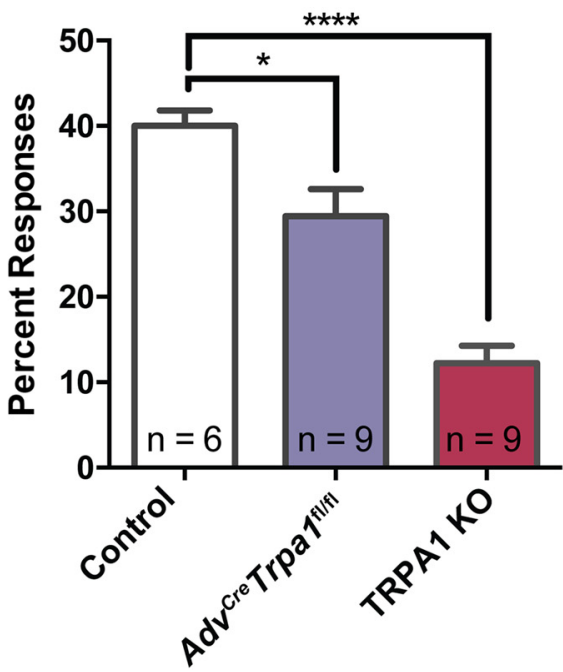

Figure 6. Advillin-Cre-mediated knock-out of TRPA1 from sensory neurons results in incomplete impairment of mechanosensation. $\boldsymbol{A}$, Paw withdrawal thresholds from both Adv ${ }^{\mathrm{Cre}} \operatorname{Trpa}^{\mathrm{fl} / \mathrm{fl}}$ and global TRPA1 KO animals were elevated compared to controls. Thresholds in $A d v^{C r e} T r p a 1^{\mathrm{fl} / \mathrm{fl}}$ mice were $113 \%$ higher than those of control mice; global KO mice displayed a $218 \%$ increase over control mice. $\boldsymbol{B}$, Similar, withdrawal frequency to a repeated stimulus was significantly impaired in both control and global KO mice. Mice in this particular experiment were habituated to the testing apparatus an hour before testing, but did not receive exposure to the apparatus prior to that day. The number of mice tested per genotype is denoted within the figure. $* p<0.05 ; * * * * p<0.0001$.

sensation and subsequent aversion in an uninjured state. More specifically, an $80 \%$ reduction of TRPA1 from sensory neurons does not produce a deficit in noxious $\left(10^{\circ} \mathrm{C}\right)$ cold sensation; this finding is consistent with previous reports in non-injury states, showing that TRPA1 is not required in the mediation of baseline cold detection (Bautista et al., 2006; Knowlton et al., 2010) or C and A $\delta$ fiber activation by cold stimulation from $32^{\circ} \mathrm{C}$ to $2^{\circ} \mathrm{C}$ (Kwan et al., 2009). However, from these data, we cannot exclude that TRPA1 may still be activated by noxious or tissue-damaging cold in naïve animals and may thereby have an impact in other paradigms of cold sensitivity. For example, global TRPA1 knock-out mice show starkly impaired nocifensive jumping responses to a $0^{\circ} \mathrm{C}$ cold plate (Karashima et al., 2009). Therefore, it is possible that TRPA1 may signal a nociceptive response to intense cold that may injure tissue, but that ion channels other than TRPA1 are sufficient to signal cold detection and aversion during non-injury conditions.

Importantly, our findings served as a comparison between two independently-generated Advillin-Cre mouse lines. The complementary findings between two methods driving TRPA1 deletion provide strong evidence that this deletion is responsible for the sensory deficits. This is of particular importance due to the sometimes unnoticed, unintentional effects of Cre recombinase expression, or from deleterious impacts of either targeted recombination or random insertion during transgenic mouse generation. In this case, random insertion of Cre using a BAC transgene (Heppenstall line) or targeted insertion (Wang line) generated similar mechanosensory deficit phenotypes when crossed with the Trpa ${ }^{\mathrm{fl} / \mathrm{fl}}$ mice.
Advillin has also been found to be expressed in Merkel cells of the glabrous epidermis and has been used as a marker of such within the skin (Ranade et al., 2014; Whiteley et al., 2015). It is therefore reasonable to be cautious when interpreting the effects of an Advillin-Cre mouse line, particularly when the gene of interest is expressed in other cell types. Importantly, an extensive search did not detect Trpa1 mRNA transcripts in epidermis isolated from mouse skin, which would include both keratinocytes and Merkel cells (Zappia et al., 2016). Therefore, it is unlikely that the present results are due to deletion of TRPA1 in Merkel cells.

Further, we show that Advillin-Cre expression was not observed in keratinocytes of the skin, and such expression was also absent from spinal cord sections (data not shown). This important confirmation of tissue specificity of Cre expression suggests that any other potential sites of TRPA1 expression (e.g., keratinocytes, spinal cord astrocytes) would be unaffected in this particular study. As such, the deficit in mechanosensitivity in these AdvillinCre-Trpa $1^{f l / f l}$ mice can be attributed to the deletion of Trpa1 selectively from sensory neurons. That is, although the present experiments cannot exclusively preclude any nonneuronal expression of TRPA1, the results do in fact justify the many studies that have implicated neuronal TRPA1 in mechanosensation.

Given its abundant expression in sensory tissues, including sensory ganglia and inner ear hair cells (Story et al., 2003; Corey et al., 2004; Julius, 2013), it has been largely assumed that expression of TRPA1 within sensory neurons is responsible for the phenotypes observed in TRPA1-deficient animals. However, sensory neurons do 
not act in isolation. In addition to the clear role of primary sensory neurons in cutaneous sensation, keratinocytes have recently become recognized as potential players within mechanosensation, thermosensation and nociception (Peier et al., 2002; Chung et al., 2004; Denda et al., 2007; Baumbauer et al., 2015; Pang et al., 2015). Given their location, epidermal keratinocytes are uniquely poised to respond to external stimuli, and indeed are capable signaling this information to sensory neurons through release of several paracrine mediators, including ATP, prostaglandins, endothelin-1, interleukins, or other cytokines (Southall et al., 2003; Lumpkin and Caterina, 2007; Huang et al., 2008; Olaru and Jensen, 2010; Azorin et al., 2011; Shi et al., 2013; Zappia et al., 2016).

The expression of TRPA1 within nonneuronal tissues has been proposed and debated. For example, there are reports of TRPA1 expression in mouse and human skin (Atoyan et al., 2009; Kwan and Corey, 2009); however, in other studies, expression of Trpa1 mRNA was not detected in mouse epidermis (Liu et al., 2013; Zappia et al., 2016). Thus, it has remained important to directly address whether the in vivo functional role of TRPA1 in mediating baseline mechanical sensitivity is mediated by sensory neurons or nonneuronal cell types. Importantly, our data present strong evidence that deletion of TRPA1 selectively from a majority $(80 \%)$ of sensory neurons is sufficient to induce a strong mechanosensory deficit both behaviorally and at the level of isolated sensory neurons. These data also suggest that even if TRPA1 is expressed in other cell types, this extraneuronal TRPA1 is not sufficient to maintain mechanical sensory function. As such, TRPA1 within sensory neurons is of intrinsic importance in mediating mechanical sensation.

In all, these results provide evidence from two complementary and independent Advillin-Cre mouse lines indicating that TRPA1 specifically expressed within sensory neurons is essential for normal baseline sensitivity to multiple types of mechanical stimuli. These mouse lines should be a valuable asset for mechanistically dissecting the sensory neuron TRPA1 contribution to a variety of other chronic pain and itch conditions.

\section{References}

Atoyan R, Shander D, Botchkareva NV (2009) Non-neuronal expression of transient receptor potential type A1 (TRPA1) in human skin. $\mathrm{J}$ Invest Dermatol 129:2312-2315. CrossRef Medline

Aubdool AA, Graepel R, Kodji X, Alawi KM, Bodkin JV, Srivastava S, Gentry C, Heads R, Grant AD, Fernandes ES, Bevan S, Brain SD (2014) TRPA1 is essential for the vascular response to environmental cold exposure. Nat Commun 5:5732. CrossRef Medline

Azorin N, Raoux M, Rodat-Despoix L, Merrot T, Delmas P, Crest M (2011) ATP signalling is crucial for the response of human keratinocytes to mechanical stimulation by hypo-osmotic shock. Exp Dermatol 20:401-407. CrossRef Medline

Bandell M, Story GM, Hwang SW, Viswanath V, Eid SR, Petrus MJ, Earley TJ, Patapoutian A (2004) Noxious cold ion channel TRPA1 is activated by pungent compounds and bradykinin. Neuron 41: 849-857. Medline

Barabas ME, Kossyreva EA, Stucky CL (2012) TRPA1 is functionally expressed primarily by IB4-binding, non-peptidergic mouse and rat sensory neurons. PLoS One 7:e47988. CrossRef
Baumbauer KM, DeBerry JJ, Adelman PC, Miller RH, Hachisuka J, Lee KH, Ross SE, Koerber HR, Davis BM, Albers KM (2015) Keratinocytes can modulate and directly initiate nociceptive responses. Elife 4. CrossRef

Bautista DM, Jordt S-E, Nikai T, Tsuruda PR, Read AJ, Poblete J, Yamoah EN, Basbaum Al, Julius D (2006) TRPA1 mediates the inflammatory actions of environmental irritants and proalgesic agents. Cell 124:1269-1282. CrossRef Medline

Bautista DM, Pellegrino M, Tsunozaki M (2013) TRPA1: a gatekeeper for inflammation. Annu Rev Physiol 75:181-200.

Bautista DM, Siemens J, Glazer JM, Tsuruda PR, Basbaum Al, Stucky CL, Jordt S-E, Julius D (2007) The menthol receptor TRPM8 is the principal detector of environmental cold. Nature 448:204-208. CrossRef Medline

Blount P, Sukharev SI, Schroeder MJ, Nagle SK, Kung C (1996) Single residue substitutions that change the gating properties of a mechanosensitive channel in Escherichia coli. Proc Natl Acad Sci USA 93:11652-11657. Medline

Brierley SM, Castro J, Harrington AM, Hughes PA, Page AJ, Rychkov GY, Blackshaw LA (2011) TRPA1 contributes to specific mechanically activated currents and sensory neuron mechanical hypersensitivity. J Physiol 589:3575-3593. CrossRef Medline

Brierley SM, Hughes PA, Page AJ, Kwan KY, Martin CM, O'Donnell TA, Cooper NJ, Harrington AM, Adam B, Liebregts T, Holtmann G, Corey DP, Rychkov GI, Blackshaw LA (2009) The ion channel TRPA1 is required for normal mechanosensation and is modulated by algesic stimuli. Gastroenterology 137:2084-2095. CrossRef Medline

Brohawn SG, Su Z, MacKinnon R (2014) Mechanosensitivity is mediated directly by the lipid membrane in TRAAK and TREK1 $\mathrm{K}+$ channels. Proc Natl Acad Sci USA 111:3614-3619. CrossRef Medline

Caterina MJ (2000) Impaired nociception and pain sensation in mice lacking the capsaicin receptor. Science 288:306-313. Medline

Chaplan SR, Bach FW, Pogrel JW, Chung JM, Yaksh TL (1994) Quantitative assessment of tactile allodynia in the rat paw. J Neurosci Methods 53:55-63. Medline

Chung M-K, Lee H, Mizuno A, Suzuki M, Caterina MJ (2004) TRPV3 and TRPV4 mediate warmth-evoked currents in primary mouse keratinocytes. J Biol Chem 279:21569-21575. CrossRef Medline

Colburn RW, Lubin M, Lou Stone DJ, Wang Y, Lawrence D, D'Andrea MR, Brandt MR, Liu Y, Flores CM, Qin N (2007) Attenuated cold sensitivity in TRPM8 null mice. Neuron 54:379-386. CrossRef Medline

Corey DP, García-Añoveros J, Holt JR, Kwan KY, Lin S-Y, Vollrath MA, Amalfitano A, Cheung EL-M, Derfler BH, Duggan A, Géléoc GSG, Gray PA, Hoffman MP, Rehm HL, Tamasauskas D, Zhang D-S (2004) TRPA1 is a candidate for the mechanosensitive transduction channel of vertebrate hair cells. Nature 432:723-730. CrossRef

Coste B, Mathur J, Schmidt M, Earley TJ, Ranade S, Petrus MJ, Dubin AE, Patapoutian A (2010) Piezo1 and Piezo2 are essential components of distinct mechanically activated cation channels. Science 330:55-60. CrossRef Medline

Cox CD, Bae C, Ziegler L, Hartley S, Nikolova-Krstevski V, Rohde PR, Ng C-A, Sachs F, Gottlieb PA, Martinac B (2016) Removal of the mechanoprotective influence of the cytoskeleton reveals $\mathrm{PI}$ EZO1 is gated by bilayer tension. Nat Commun 7:1-13. CrossRef da Silva S, Hasegawa H, Scott A, Zhou X, Wagner AK, Han B-X, Wang $F$ (2011) Proper formation of whisker barrelettes requires periphery-derived Smad4-dependent TGF-beta signaling. Proc Natl Acad Sci USA 108:3395-3400. CrossRef Medline

del Camino D, Murphy S, Heiry M, Barrett LB, Earley TJ, Cook CA, Petrus MJ, Zhao M, D'Amours M, Deering N, Brenner GJ, Costigan M, Hayward NJ, Chong JA, Fanger CM, Woolf CJ, Patapoutian A, Moran MM (2010) TRPA1 contributes to cold hypersensitivity. J Neurosci 30:15165-15174. CrossRef Medline

Denda M, Nakatani M, Ikeyama K, Tsutsumi M, Denda S (2007) Epidermal keratinocytes as the forefront of the sensory system. Exp Dermatol 16:157-161. CrossRef Medline 
Dirajlal S, Pauers LE, Stucky CL (2003) Differential response properties of IB(4)-positive and -negative unmyelinated sensory neurons to protons and capsaicin. J Neurophysiol 89:513-524. CrossRef Medline

Dixon WJ (1980) Efficient analysis of experimental observations. Annu Rev Pharmacol Toxicol 20:441-462. CrossRef Medline

Eid SR, Crown ED, Moore EL, Liang HA, Choong K-C, Dima S, Henze DA, Kane SA, Urban MO (2008) HC-030031, a TRPA1 selective antagonist, attenuates inflammatory- and neuropathy-induced mechanical hypersensitivity. Mol Pain 4:48. CrossRef Medline

Everaerts W, Gees M, Alpizar YA, Farre R, Leten C, Apetrei A, Dewachter I, van Leuven F, Vennekens R, De Ridder D, Nilius B, Voets T, Talavera K (2011) The capsaicin receptor TRPV1 is a crucial mediator of the noxious effects of mustard oil. Curr Biol 21:316-321. CrossRef

Garrison SR, Stucky CL (2014) Contribution of transient receptor potential ankyrin 1 to chronic pain in aged mice with complete Freund's adjuvant-induced arthritis. Arthritis Rheumatol 66:23802390. CrossRef

Hargreaves K, Dubner R, Brown F, Flores C, Joris J (1988) A new and sensitive method for measuring thermal nociception. Pain 32:7788. Medline

Hasegawa H, Abbott S, Han B-X, Qi Y, Wang F (2007) Analyzing somatosensory axon projections with the sensory neuron-specific Advillin gene. J Neurosci 27:14404-14414. CrossRef Medline

Hogan Q, Sapunar D, Modric-Jednacak K, McCallum JB (2004) Detection of neuropathic pain in a rat model of peripheral nerve injury. Anesthesiology 101:476-487. Medline

Huang SM, Lee H, Chung M-K, Park U, Yu YY, Bradshaw HB, Coulombe PA, Walker JM, Caterina MJ (2008) Overexpressed transient receptor potential vanilloid 3 ion channels in skin keratinocytes modulate pain sensitivity via prostaglandin E2. J Neurosci 28:13727-13737. CrossRef Medline

Jordt S-E, Bautista DM, Chuang H, McKemy DD, Zygmunt PM, Högestätt ED, Meng ID, Julius D (2004) Mustard oils and cannabinoids excite sensory nerve fibres through the TRP channel ANKTM1. Nature 427:260-265. CrossRef Medline

Julius D (2013) TRP channels and pain. Annu Rev Cell Dev Biol 29:355-384. CrossRef Medline

Karashima Y, Talavera K, Everaerts W, Janssens A, Kwan KY, Vennekens R, Nilius B, Voets T (2009) TRPA1 acts as a cold sensor in vitro and in vivo. Proc Natl Acad Sci USA 106:1273-1278. CrossRef Medline

Kerstein PC, del Camino D, Moran MM, Stucky CL (2009) Pharmacological blockade of TRPA1 inhibits mechanical firing in nociceptors. Mol Pain 5:19. CrossRef Medline

Knowlton WM, Fisher A, Bautista DM, McKemy DD (2010) TRMP8, but not TRPA1, is required for neural and behavioral responses to acute noxious cold temperatures and cold-mimetics in vivo. Pain 150:340-350. CrossRef Medline

Kobayashi K, Fukuoka T, Obata K, Yamanaka H, Dai Y, Tokunaga A, Noguchi K (2005) Distinct expression of TRPM8, TRPA1, and TRPV1 mRNAs in rat primary afferent neurons with $A \delta / C$-fibers and colocalization with Trk receptors. J Comp Neur 493:596-606. CrossRef Medline

Kung C, Martinac B, Sukharev S (2010) Mechanosensitive channels in microbes. Annu Rev Microbiol 64:313-329. CrossRef Medline

Kwan KY, Allchorne AJ, Vollrath MA, Christensen AP, Zhang D-S, Woolf CJ, Corey DP (2006) TRPA1 contributes to cold, mechanical, and chemical nociception but is not essential for hair-cell transduction. Neuron 50:277-289. CrossRef Medline

Kwan KY, Corey DP (2009) Burning cold: involvement of TRPA1 in noxious cold sensation. J Gen Physiol 133:251-256. CrossRef Medline

Kwan KY, Glazer JM, Corey DP, Rice FL, Stucky CL (2009) TRPA1 modulates mechanotransduction in cutaneous sensory neurons. $J$ Neurosci 29:4808-4819. CrossRef Medline

Lennertz RC, Kossyreva EA, Smith AK, Stucky CL (2012) TRPA1 mediates mechanical sensitization in nociceptors during inflammation. PLoS One 7:e43597. CrossRef Medline
Liu B, Fan L, Balakrishna S, Sui A, Morris JB, Jordt S-E (2013) TRPM8 is the principal mediator of menthol-induced analgesia of acute and inflammatory pain. Pain 154:2169-2177. CrossRef Medline

Lumpkin EA, Caterina MJ (2007) Mechanisms of sensory transduction in the skin. Nature 445:858-865. CrossRef Medline

Minett M, Nassar M, Clark A, Passmore G, Dickenson A, Wang F, Malcangio M, Wood J (2012) Distinct Nav1.7-dependent pain sensations require different sets of sensory and sympathetic neurons. Nat Commun 3:791-799. CrossRef Medline

Nilius B, Honoré E (2012) Sensing pressure with ion channels. Trends Neurosci 35:477-486. CrossRef Medline

Obata K, Katsura H, Mizushima T, Yamanaka H, Kobayashi K, Dai Y, Fukuoka T, Tokunaga A, Tominaga M, Noguchi K (2005) TRPA1 induced in sensory neurons contributes to cold hyperalgesia after inflammation and nerve injury. J Clin 115:2393-2401. Investivation CrossRef

Olaru F, Jensen LE (2010) Chemokine expression by human keratinocyte cell lines after activation of Toll-like receptors (TLRs). Exp Dermatol 19:314-316. CrossRef

Pagadala P, Park C-K, Bang S, Xu Z-Z, Xie R-G, Liu T, Han B-X, Tracey WD, Wang F, Ji R-R (2013) Loss of NR1 subunit of NMDARs in primary sensory neurons leads to hyperexcitability and pain hypersensitivity: involvement of $\mathrm{Ca} 2+$-activated small conductance potassium channels. J Neurosci 33:13425-13430. CrossRef

Pang Z, Sakamoto T, Tiwari V, Kim Y-S, Yang F, Dong X, Güler AD, Guan Y, Caterina MJ (2015) Selective keratinocyte stimulation is sufficient to evoke nociception in mice. Pain 156:656-665. CrossRef Medline

Paulsen CE, Armache J, Gao Y, Cheng Y, Julius D (2015) Structure of the TRPA1 ion channel suggests regulatory mechanisms. Nature 520:511-517. CrossRef Medline

Peier AM, Reeve AJ, Andersson DA, Moqrich A, Earley TJ, Hergarden AC, Story GM, Colley S, Hogenesch JB, Mclntyre P, Bevan S, Patapoutian A (2002) A heat-sensitive TRP channel expressed in keratinocytes. Science 296:2046-2049. (80-) CrossRef

Petrus M, Peier AM, Bandell M, Hwang SW, Huynh T, Olney N, Jegla T, Patapoutian A (2007) A role of TRPA1 in mechanical hyperalgesia is revealed by pharmacological inhibition. Mol Pain 3:40. CrossRef Medline

Ranade SS, Woo S-H, Dubin AE, Moshourab RA, Wetzel C, Petrus M, Mathur J, Bégay V, Coste B, Mainquist J, Wilson A, Francisco AG, Reddy K, Quu Z, Wood JN, Lewin GR, Patapoutian A (2014) Piezo2 is the major transducer of mechanical forces for touch sensation in mice. Nature 516:121-125. CrossRef Medline

Shi X, Wang L, Clark JD, Kingery WS (2013) Keratinocytes express cytokines and nerve growth factor in response to neuropeptide activation of the ERK1/2 and JNK MAPK transcription pathways. Regul Pept 186:92-103. CrossRef Medline

Shigetomi E, Tong X, Kwan KY, Corey DP, Khakh BS (2012) TRPA1 channels regulate astrocyte resting calcium and inhibitory synapse efficacy through GAT-3. Nat Neurosci 15:70-80. CrossRef Medline

Southall MD, Li T, Gharibova LS, Pei Y, Nicol GD, Travers JB (2003) Activation of epidermal vanilloid receptor-1 induces release of proinflammatory mediators in human keratinocytes. 304:217-222. CrossRef Medline

Story GM, Peier AM, Reeve AJ, Eid SR, Mosbacher J, Hricik TR, Earley TJ, Hergarden AC, Andersson DA, Hwang SW, Mclntyre P, Jegla T, Bevan S, Patapoutian A (2003) ANKTM1, a TRP-like channel expressed in nociceptive neurons, is activated by cold temperatures. Cell 112:819-829. Medline

Vilceanu D, Stucky CL (2010) TRPA1 mediates mechanical currents in the plasma membrane of mouse sensory neurons. PLoS One 5:e12177. CrossRef Medline

Wang YY, Chang RB, Allgood SD, Silver WL, Liman ER (2011) A TRPA1-dependent mechanism for the pungent sensation of weak acids. J Gen Physiol 137:493-505. CrossRef Medline 
Whiteley SJ, Knutsen PM, Matthews DW, Kleinfeld D (2015) Deflection of a vibrissa leads to a gradient of strain across mechanoreceptors in a mystacial follicle. J Neurophysiol 114:138-145. CrossRef Medline

Woo S-H, Ranade S, Weyer AD, Dubin AE, Baba Y, Qiu Z, Petrus M, Miyamoto T, Reddy K, Lumpkin E. a, Stucky CL, Patapoutian A (2014) Piezo2 is required for Merkel-cell mechanotransduction. Nature 509:622-626. CrossRef Medline

Zappia KJ, Garrison SR, Palygin O, Weyer AD, Barabas ME, Lawlor MW, Staruschenko A, Stucky CL (2016) Mechanosensory and ATP release deficits following Keratin14-Cre-mediated TRPA1 deletion despite absence of TRPA1 in murine keratinocytes. PLoS One 11:e0151602. CrossRef Medline
Zayats V, Samad A, Minofar B, Roelofs KE, Stockner T, Ettrich R (2013) Regulation of the transient receptor potential channel TRPA1 by its $\mathrm{N}$-terminal ankyrin repeat domain. J Mol Model 19:4689-4700. CrossRef Medline

Zhao M, Isami K, Nakamura S, Shirakawa H, Nakagawa T, Kaneko S (2012) Acute cold hypersensitivity characteristically induced by oxaliplatin is caused by the enhanced responsiveness of TRPA1 in mice. Mol Pain 8:55. CrossRef Medline

Zurborg S, Piszczek A, Martínez C, Hublitz P, al Banchaabouchi M, Moreira P, Perlas E, Heppenstall PA (2011) Generation and characterization of an Advillin-Cre driver mouse line. Mol Pain 7:66. CrossRef Medline 